\title{
Phythoremediasi Chromium Total (Cr-T) menggunakan kayu apu (Pistia stratiotes L.) pada limbah cair batik
}

\author{
Study on batik liquid waste: Phythoremediation Chromium Total (Cr-T) \\ using Pistia stratiotes L.
}

\author{
Alif Resti Billah, Anita Dewi Moelyaningrum, Prehatin Trirahayu Ningrum \\ Kesehatan Lingkungan dan Kesehatan dan Keselamatan Kerja, \\ Fakultas Kesehatan Masyarakat, Universitas Jember, \\ Jl. Kalimantan 1 no.93 Jember - Jawa Timur - 68121 \\ *Email: anitamoelyani@gmail.comatauanitadm@unej.ac.id
}

\author{
Diterima 7 Januari 2020 Disetujui 30 Mei 2020
}

\section{INTISARI}

Industri batik dalam proses kegiatannya menghasilkan limbah cair yang mengandung logam berat chromium total. Kandungan logam chromium selain dapat menyebabkan pencemaran terhadap lingkungan juga berdampak keracunan akut dan kronis terhadap manusia. Pistia stratiotes L. termasuk tanaman fitoremediator yang dapat mengikat logam berat pada jaringan akar. Penelitian ini bertujuan untuk menganalisis perbedaan kadar logam chromium dalam limbah cair batik. Pada penelitian ini menggunakan true experiment dengan desain penelitan post-only control group design dan menggunakan metode Rancangan Acak Lengkap dengan enam kali pengulangan. Sampel terdiri dari kelompok kontrol (K) 0 gr/6L dan kelompok perlakuan yaitu $300 \mathrm{gr} / 6 \mathrm{~L}$ (P1), $350 \mathrm{gr} / 6 \mathrm{~L}$ (P2) dan $400 \mathrm{gr} / 6 \mathrm{~L}$ (P3). Limbah batik diencerkan menggunakan aquades dengan perbandingan 1:5, lalu dikontakkan dengan tanaman kayu apu selama 10 hari. Pada waktu pengontakan juga diukur $\mathrm{pH}$ dan suhu. Data dianalisis menggunakan normalitas data, homogenitas data serta uji statistik one way anova. Antara kelompok $\mathrm{K}$ dengan P1, P2, P3 menunjukkan perbedaan yang signifikan ( $\mathrm{P} 1=0.007 ; \mathrm{P} 2=0.000$ dan $\mathrm{P} 3=0.000)$.

Kata kunci: chromium total (Cr-T), fitoremediasi, kayu apu, limbah cair batik

\begin{abstract}
The batik industry produce chromium $(\mathrm{Cr})$ waste. The chromium can cause acute dan chronic poisoning in humans and environmental pollution. Pistia stratiotes $L$ is a phytoremediator plant that can bind heavy metals to the root tissue. Analyze the differences of chromium levels wih Pistia stratiotes $L$ as phytoremediation is the purpose of this study. This research is a true experiment with only post control group design and uses a completely randomized design method with six repetitions. The sample were control group $0 \mathrm{gr} / 6 \mathrm{~L}(\mathrm{~K})$ and a treatment group of $300 \mathrm{gr} / 6 \mathrm{~L}(\mathrm{P} 1), 350 \mathrm{gr} / 6 \mathrm{~L}(\mathrm{P} 2)$ and $400 \mathrm{gr} / 6 \mathrm{~L}(\mathrm{P} 3)$. Batik liquid waste was diluted using aquades in 1:5 ratio, then contacted with Pistia stratiotes L. for 10 days. The $\mathrm{pH}$ and temperature were measured. Data were analyzed using data normality, data homogenity and continued with one way Anova statistical test. The results between $\mathrm{K}$ with P1, P2, P3 show there is significant differences $(\mathrm{P} 1=0.007 ; \mathrm{P} 2=0.000$ dan $\mathrm{P} 3=0.000)$.
\end{abstract}

Keywords: chromium total (Cr-T), phytoremediation, Pistia stratiotes L, batik liquid waste 


\section{PENDAHULUAN}

Industri batik di Indonesia berkembang pesat mendorong meningkatnya perekonomian negara. Namun demikian, industri ini juga memiliki potensi untuk mencemari lingkungan karena limbah cairnya. Pada umumnya limbah ini mengandung logam berat Chromium (Cr). Limbah ini harus diolah dahulu sebelum dibuang ke lingkungan. Jika langsung dibuang ke lingkungan akan menurunkan kualitas lingkungan dan merusak habitat yang hidup sekitar aliran sungai (Andriani \& Hartini, 2017).

Proses pembuatan kain batik yang dilakukan industri batik menggunakan bahan-bahan kimia dan air (Sari et al., 2014). Bahan kimia mengandung padatan tersuspensi, zat organik dan anorganik yang mengandung logam berat. Penggunaan kimia biasanya digunakan pada saat proses pewarnaan dan pencelupan kain batik yang mana pada proses tersebut menghasilkan limbah cair. Chromium ditemukan dalam limbah batik (Pridyanti et al., 2018), (Zarkasi et al., 2018).

Logam chromium (Cr) dapat menyebabkan keracunan akut yaitu muntah, diare berdarah, gangguan saluran pencernaan, nekrosis hati, nekrosis ginjal dan keracunan. Sedangkan keracunan kronis juga dapat terjadi yaitu iritasi kulit, gangguan pada hati, syaraf bahkan kanker paru-paru (Nurkhasanah, 2015). Logam chromium juga berdampak pada penurunan kualitas air dan mengganggu organisme akuatik yang dapat berdampak kematian organisme (Setiyono \& Gustaman, 2017). Pencemaran logam chromium perlu dilakukan penanggulangan untuk mengurangi dampak berbahaya bagi lingkungan yaitu dengan metode fitoremediasi, karena biaya yang lebih rendah, tidak memerlukan peralatan khusus dan mudah diterapkan karena sumber daya tumbuhan yang melimpah.

Pistia stratiotes L. memiliki kemampuan untuk mengolah limbah, baik itu berupa logam berat, zat organik maupun anorganik sehingga tanaman ini digolongkan salah satu tumbuhan fitoremediator. Kayu apu berlimpah di alam, mudah ditemukan mengapung di perairan atau kolam serta tanaman gulma air terutama di tanaman padi. Pistia stratiotes L. juga memiliki kelebihan yaitu berkecambah yang tinggi, pertumbuhan cepat, tingkat absorbsi atau penyerapan unsur hara dan air yang besar dan daya adaptasi yang tinggi terhadap iklim (Fachrurozi et al., 2010). Pistia stratiotes L. atau kayu apu terbukti dapat menurunkan logam berat merkuri (Hg) dalam air (Khasanah et al., 2018). Penelitian lain yang telah dilakukan sebelumnya (Raissa \& Tangahu, 2017) penambahan kayu apu dapat menurunkan konsentrasi limbah cair pada limbah laundry yaitu BOD sebesar 98\%, COD sebesar $96 \%$ dan fosfat $99 \%$. Menurut (Perwitasari et al., 2018) tanaman kayu apu mampu menurunkan kandungan $\mathrm{Pb}$ lebih tinggi dibandingkan tanaman Echinodorus radicans sebesar $92.53 \%$ dan $89.59 \%$. Berdasarkan uraian tersebut, dalam penelitian ini kayu apu digunakan sebagai tanaman fitoremediasi dalam menyerap logam Cr. Penelitian ini memiliki tujuan yaitu menganalisis perbedaan kadar logam chromium dalam limbah cair batik yang dikontakkan dan tidak dikontakkan dengan tanaman kayu apu dengan variasi berat $300 \mathrm{gr} / 6 \mathrm{~L}$, $350 \mathrm{gr} / 6 \mathrm{~L}$ dan $400 \mathrm{gr} / 6 \mathrm{~L}$ dalam waktu pengontakan 10 hari

\section{MATERI DAN METODE}

\section{Tempat dan waktu penelitian}

Penelitian terdiri dari dua tempat yaitu tempat pengontakan limbah cair dengan tanaman kayu apu dilakukan di Laboratorium Fakultas Kesehatan Masyarakat Universitas Jember dan tempat pemeriksaan kadar chromium dilakukan di Laboratorium Kesehatan Daerah Kabupaten Jember. Waktu penelitian dilaksanakan pada September 2019-Desember 2019.

\section{Bahan dan alat}

Alat dan bahan yang digunakan adalah jirigen ukuran 25 liter, bak penelitian dengan ukuran volume > 6 liter sebanyak 24 buah, pengaduk, timbangan analitik, $\mathrm{pH}$ meter, thermometer, botol plastik sebanyak 24 buah, limbah cair batik, akuades, dan tanaman kayu apu. 


\section{Metode}

Penelitian ini adalah True Experimental dengan bentuk Post-test Only Control Group Design dan menggunakan analisis Rancangan Acak Lengkap. Penelitian ini terbagi menjadi 4 kelompok, yaitu satu kelompok kontrol atau tanpa kayu apu (0 gr/6L) dan tiga kelompok perlakuan yaitu P1 (300 gr/6L), P2 (350 gr/6L), dan P3 (400 gr/6L). Pengulangan dilakukan sebanyak 6 kali pada setiap kelompok sehingga total 24 sampel. Limbah cair batik sebelum dilakukan pengontakan diencerkan terlebih dahulu menggunakan aquadest dengan perbandingan 1:5. Kadar awal Cr-T dalam penelitian ini sama dengan kelompok $\mathrm{K}$ yaitu 0,509 dikarenakan metode dalam penelitian menggunakan post-test control design. Tanaman kayu apu yang digunakan yaitu dengan kriteria jumlah daun 7-10 helai, diameter 5-8 cm dan panjang akar 5-7 cm. Kayu apu dalam penelitian ini sebelum dikontakkan dengan limbah, maka dilakukan aklimatisasi terlebih dahulu selama tujuh hari. Lama pengontakan selama 10 hari dan dilakukan juga pengukuran $\mathrm{pH}$ dan suhu dimana diukur 3 waktu dalam satu hari selama 10 hari yaitu pukul 07.00 WIB, 12.00 WIB dan 17.00 WIB.

\section{Analisis data}

Uji statistik yang digunakan yaitu uji normalitas menggunakan Kolmogorov Smirnov. Jika hasil berdistribusi normal maka dilanjutkan dengan uji one way anova jika berdistribusi tidak normal maka diuji dengan Kruskal Wallis.

\section{HASIL}

Berdasarkan Tabel 1 diketahui bahwa hasil rerata $\mathrm{pH}$ pada kelompok $\mathrm{K}$ sebesar 9.9; P1 sebesar 9; P2 sebesar 8.9 dan P3 sebesar 8.6. Rerata suhu limbah cair batik selama 10 hari waktu pengontakan dengan tanaman kayu apu mengalami peningkatan yaitu $26^{\circ} \mathrm{C}$ menjadi $27^{\circ} \mathrm{C}$.

Tabel 1. Pengukuran pH dan suhu kelompok kontrol (K) dan kelompok perlakuan (P1, P2 dan P3)

\begin{tabular}{|c|c|c|c|c|c|c|}
\hline Kelompok & & $\mathrm{pH}$ & Rerata & & Suhu $\left({ }^{\circ} \mathrm{C}\right)$ & Rerata \\
\hline \multirow{10}{*}{ K (Kontrol) } & 1 & 10.1 & \multirow{10}{*}{$\bar{X}=9.9$} & 1 & 26 & \multirow{10}{*}{$\bar{X}=26^{\circ} \mathrm{C}$} \\
\hline & 2 & 10.6 & & 2 & 26 & \\
\hline & 3 & 10.2 & & 3 & 26 & \\
\hline & 4 & 9.7 & & 4 & 26 & \\
\hline & 5 & 9.6 & & 5 & 26 & \\
\hline & 6 & 9.8 & & 6 & 27 & \\
\hline & 7 & 9.7 & & 7 & 27 & \\
\hline & 8 & 9.9 & & 8 & 26 & \\
\hline & 9 & 9.9 & & 9 & 26 & \\
\hline & 10 & 9.9 & & 10 & 26 & \\
\hline \multirow{10}{*}{$\mathrm{P} 1$} & 1 & 10.1 & \multirow{10}{*}{$\bar{X}=9$} & 1 & 26 & \multirow{10}{*}{$\bar{X}=26^{\circ} \mathrm{C}$} \\
\hline & 2 & 9.9 & & 2 & 27 & \\
\hline & 3 & 9.3 & & 3 & 27 & \\
\hline & 4 & 9.3 & & 4 & 26 & \\
\hline & 5 & 8.8 & & 5 & 26 & \\
\hline & 6 & 8.6 & & 6 & 26 & \\
\hline & 7 & 8.6 & & 7 & 27 & \\
\hline & 8 & 8.5 & & 8 & 26 & \\
\hline & 9 & 8.4 & & 9 & 26 & \\
\hline & 10 & 8.5 & & 10 & 27 & \\
\hline \multirow{10}{*}{$\mathrm{P} 2$} & 1 & 10.1 & \multirow{10}{*}{$\bar{X}=8.9$} & 1 & 26 & \multirow{10}{*}{$\bar{X}=27^{\circ} \mathrm{C}$} \\
\hline & 2 & 9.8 & & 2 & 27 & \\
\hline & 3 & 9.2 & & 3 & 27 & \\
\hline & 4 & 9.1 & & 4 & 27 & \\
\hline & 5 & 8.8 & & 5 & 27 & \\
\hline & 6 & 8.7 & & 6 & 27 & \\
\hline & 7 & 8.5 & & 7 & 27 & \\
\hline & 8 & 8.3 & & 8 & 27 & \\
\hline & 9 & 8.2 & & 9 & 27 & \\
\hline & 10 & 8.1 & & 10 & 27 & \\
\hline
\end{tabular}


Tabel 1 (lanj). Pengukuran pH dan suhu kelompok kontrol (K) dan kelompok perlakuan (P1, P2 dan P3)

\begin{tabular}{ccccccc}
\hline Kelompok & & $\mathrm{pH}$ & Rerata & & Suhu $\left({ }^{\circ} \mathrm{C}\right)$ & Rerata \\
\hline & 1 & 10.1 & & 1 & 26 & \\
& 2 & 9.9 & & 2 & 27 & \\
& 3 & 9.2 & & 3 & 27 & \\
P3 & 4 & 8.3 & & 4 & 27 & \\
& 5 & 8.1 & $\bar{X}=8.6$ & 5 & 26 & $\bar{X}=27^{\circ} \mathrm{C}$ \\
& 6 & 8.1 & & 6 & 27 & \\
& 7 & 8.1 & & 7 & 27 & \\
& 8 & 8.1 & & 8 & 27 & \\
& 9 & 8.1 & & 9 & 27 & \\
\hline
\end{tabular}

Berdasarkan gambar 1 diketahui bahwa setiap replikasi memiliki hasil yang berbeda-beda. Pada kelompok K hasil kadar Cr tertinggi terdapat pada replikasi ketiga yaitu $0.61 \mathrm{mg} / \mathrm{L}$ dan terendah pada replikasi keempat yaitu $0.403 \mathrm{mg} / \mathrm{L}$. Pada kelompok $\mathrm{P}_{1}$ kadar $\mathrm{Cr}$ tertinggi terdapat pada replikasi kedua yaitu $0.4 \mathrm{mg} / \mathrm{L}$ dan terendah pada replikasi pertama yaitu $0.34 \mathrm{mg} / \mathrm{L}$. Pada kelompok $\mathrm{P}_{2}$ kadar Cr-T tertinggi terdapat pada replikasi pertama yaitu $0.319 \mathrm{mg} / \mathrm{L}$ dan terendah pada replikasi kedua yaitu $0.234 \mathrm{mg} / \mathrm{L}$. Pada kelompok $\mathrm{P}_{3}$ kadar Cr-T tertinggi terdapat pada replikasi pertama yaitu $0.212 \mathrm{mg} / \mathrm{L}$ dan terendah pada replikasi keempat yaitu $0.137 \mathrm{mg} / \mathrm{L}$.

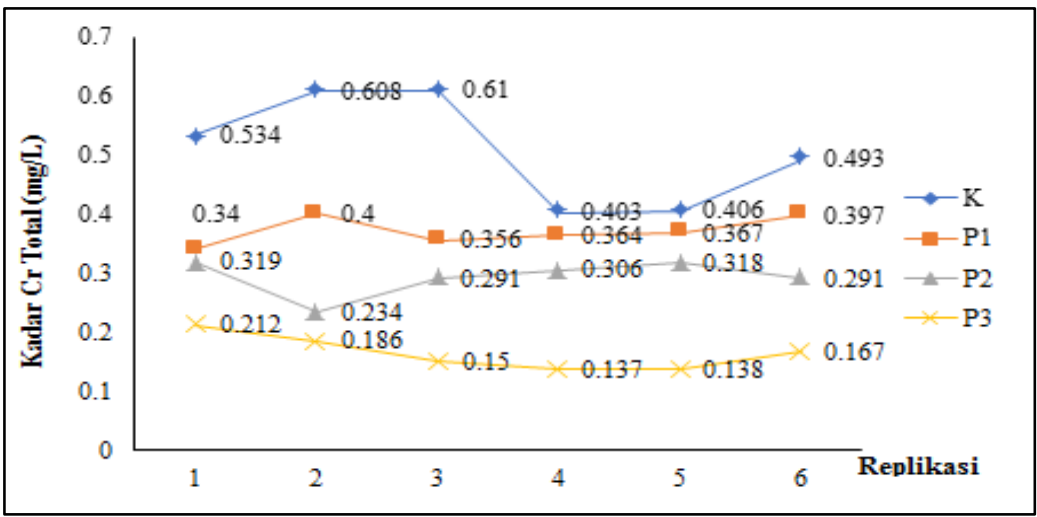

Gambar 1. Kadar Cr-total pada kelompok kontrol (K) dan kelompok perlakuan (P1, P2, P3)

Berdasarkan gambar 2 diketahui bahwa rerata kadar Cr terdapat perbedaan pada masing-masing kelompok. Rerata pada kelompok tanpa kayu apu (K) sebesar $0.509 \mathrm{mg} / \mathrm{L}$. Rerata penurunan kadar
Cr terjadi pada kelompok P1 yaitu sebesar 0.371 $\mathrm{mg} / \mathrm{L}$, kelompok P2 yaitu sebesar $0.293 \mathrm{mg} / \mathrm{L}$ dan kelompok P3 yaitu sebesar $0.165 \mathrm{mg} / \mathrm{L}$.

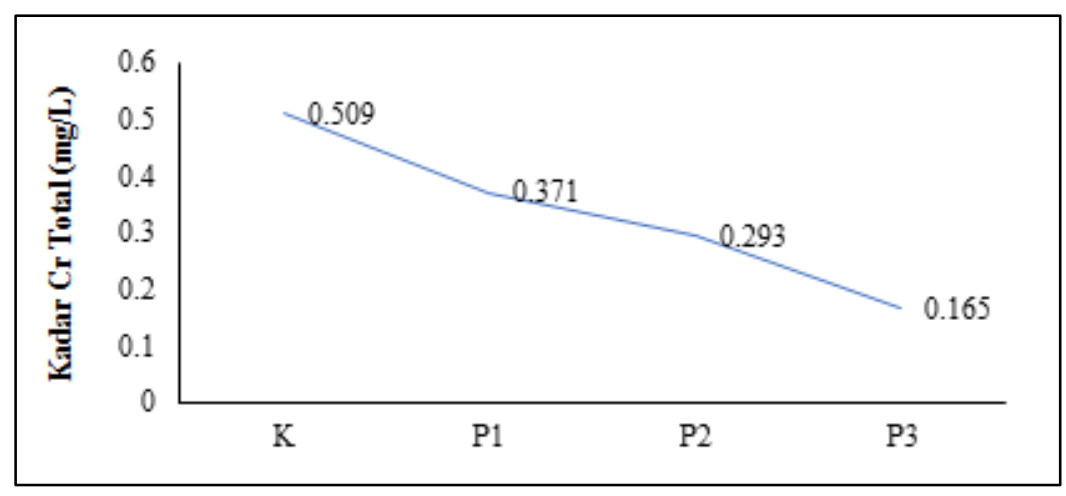

Gambar 2. Rerata kadar Cr pada kelompok kontrol (K) dan kelompok perlakuan (P1, P2, P3) 
Berdasarkan tabel 2. menunjukkan persentase penurunan terendah kadar $\mathrm{Cr}$ dibandingkan kelompok K yaitu pada kelompok P1 sebesar $27.1 \%$. Sedangkan persentase penurunan tertinggi yaitu pada kelompok P3 sebesar 67.6\%.

Tabel 2. Persentase Penurunan Kadar $\mathrm{Cr}$

\begin{tabular}{ccc}
\hline No & Kelompok & Penurunan (\%) \\
\hline 1 & $\mathrm{~K}$ & - \\
2 & $\mathrm{P}_{1}$ & 27.1 \\
\hline No & Kelompok & Penurunan $(\%)$ \\
\hline 3 & $\mathrm{P}_{2}$ & 42.4 \\
4 & $\mathrm{P}_{3}$ & 67.6 \\
\hline
\end{tabular}

Analisis data menggunakan uji statistik One Way Anova. Berdasarkan tabel 3 diketahui bahwa terdapat perbedaan nilai signifikansi antara setiap kelompok. Hasil uji post hoc menghasilkan nilai $\mathrm{P} \leq 0.05$ yang mempunyai arti secara statistik bahwa terdapat perbedaan penurunan $\mathrm{Cr}$ pada setiap kelompok perlakuan.

Tabel 3. Hasil Uji Post Hoc

\begin{tabular}{ccccc}
\hline Kelompok & $\mathrm{K}$ & $\mathrm{X}_{1}$ & $\mathrm{X}_{2}$ & $\mathrm{X}_{3}$ \\
\hline $\mathrm{K}$ & - & $0.007^{*}$ & $0.000^{*}$ & $0.000^{*}$ \\
$\mathrm{P}_{1}$ & - & - & $0.042^{*}$ & $0.000^{*}$ \\
$\mathrm{P}_{2}$ & - & - & - & $0.000^{*}$ \\
$\mathrm{P}_{3}$ & - & - & - & - \\
\hline
\end{tabular}

Keterangan: (*) menunjukkan signifikansi pada kelompok $\mathrm{K}, \mathrm{P} 1, \mathrm{P} 2$ dan P3

\section{PEMBAHASAN}

Pengukuran $\mathrm{pH}$ dan suhu bertujuan untuk mengetahui kondisi keasaman dan suhu suatu lingkungan. Pengukuran $\mathrm{pH}$ menggunakan alat $\mathrm{pH}$ meter dan didapatkan $\mathrm{pH}$ limbah cair batik di awal sama yaitu 10.1. Selanjutnya setelah dilakukan perlakuan dengan adanya penambahan kayu apu berkontribusi terjadinya penurunan $\mathrm{pH}$. Penurunan $\mathrm{pH}$ disebabkan adanya proses biodegradasi bahan organik. Bagian tanaman yang mati dari tanaman kayu apu akan diuraikan oleh mikroorganisme di dalam air, sehingga dalam proses penguraian bahan organik akan mempengaruhi nilai suatu pH (Sari et al., 2017). Aktivitas mikroorganisme pendegradasi memungkinkan terjadinya penurunan pH karena senyawa organic telah diuraikan menjadi asam organik (Purnamawati et al., 2015).
Penyebab penurunan $\mathrm{pH}$ juga dapat disebabkan karena terjadinya pembusukan bagian tanaman air oleh kerja mikroba penghasil asam. Nilai $\mathrm{pH}$ semakin menurun dapat juga terjadi karena ion $\mathrm{OH}^{-}$yang menyebabkan $\mathrm{pH}$ basa berikatan dengan ion chromium $\left(\mathrm{Cr}^{3+}\right.$ dan $\left.\mathrm{Cr}^{6+}\right)$ sehingga ion $\mathrm{OH}^{-}$dalam air limbah berkurang sehingga pH turun (Hapsari et al., 2016). Berdasarkan Peraturan Menteri Lingkungan Hidup dan Kehutanan No. 68 Tahun 2016, pada penelitian ini $\mathrm{pH}$ telah sesuai dengan baku mutu yang seharusnya yaitu rerata 8.6 dilihat dari peraturan bahwa $\mathrm{pH}$ perlakuan berada dalam kisaran 6-9. Pengukuran suhu menggunakan alat thermometer. Pada penelitian ini didapatkan suhu di awal sama yaitu $26^{\circ} \mathrm{C}$. Namun, setelah perlakuan terjadinya kenaikan yaitu yang semula $26^{\circ} \mathrm{C}$ menjadi $27^{\circ} \mathrm{C}$. Menurut (Raissa, 2017) disebabkan setiap wadah diletakkan pada lokasi yang sama. Rerata suhu pada penelitian ini $26^{\circ} \mathrm{C}$ $27^{\circ} \mathrm{C}$ telah memenuhi batas suhu optimum yang diperbolehkan yaitu suhu optimum fitoremediasi berkisar antara $25^{\circ} \mathrm{C}-30^{\circ} \mathrm{C}$ serta berada pada batas suhu optimum tanaman kayu apu tumbuh yaitu $22^{\circ} \mathrm{C}-30^{\circ} \mathrm{C}$ (Jamil et al., 2016). Suhu berkaitan dengan proses metabolisme dan fotosintesis, sehingga dengan adanya peningkatan suhu secara tidak langsung akan berpengaruh terhadap tingkat penyerapan. Menurut Ikawati et al., (2013) semakin tinggi suhu lingkungan tanaman maka semakin tinggi pula tingkat penyerapan oleh tanaman. Namun dengan peningkatan suhu juga dapat menyebabkan toksisitas meningkat sehingga pertumbuhan tanaman terhambat, yang mana pada tanaman kayu apu ditandai dengan memendeknya akar (Henrasarie, 2019).

Berdasarkan hasil laboratorium kadar $\mathrm{Cr}$ pada setiap kelompok mengalami penurunan, penurunan tertinggi yaitu $67.6 \%$. Perbedaan penurunan kadar $\mathrm{Cr}$ menunjukkan adanya hubungan ataupun pengaruh antara variasi berat kayu apu dengan penurunan kadar Cr pada limbah cair batik. Berdasarkan penelitian (Jamil et al., 2016) dan (Rahayuningtyas et al., 2018) menunjukkan hasil yang sama yaitu semakin banyak pemberian variasi berat tanaman kayu apu berbanding lurus dengan semakin besar 
penyerapan logam berat. Menurut penelitian Herlambang \& Hendriyanto (2015) menunjukkan variasi berat tanaman atau jumlah tanaman berdampak pada penurunan kadar phosfat. Semakin berat atau bertambah jumlah tanaman akan semakin besar penurunan kadar phosfat. Namun semakin banyaknya jumlah tanaman akan timbul persaingan tanaman yaitu pertumbuhan tanaman dapat terganggu dan semakin lama akan menjadi layu bahkan mati.

Kayu apu termasuk tanaman fitoremediator yaitu tanaman yang dapat digunakan untuk menyerap kandungan logam berat. Kayu apu memiliki potensial yang sangat tinggi untuk kekeruhan dan memperbaiki kualitas air. Tanaman kayu apu dapat memfilter, mengabsorpsi partikel dan ion-ion logam yang terdapat dalam air limbah melalui akar yang dimilikinya (Wirawan et al., 2014). Tanaman kayu apu memiliki akar serabut yang berfungsi sebagai tempat menempelnya koloid yang melayang di air dan juga banyak menghasilkan oksigen hasil proses fotosintesis yang dimanfaatkan mikroorganisme untuk menguraikan zat organik air limbah. Kemudian bahan organik dirombak oleh mikroorganisme menjadi senyawa lebih sederhana dan digunakan tanaman sebagai nutrient. Menurut Irhamni et al., (2018) terdapat tiga mekanisme penyerapan dalam tumbuhan yaitu penyerapan oleh akar, translokasi logam dari akar ke bagian tumbuhan lain dan lokalisasi logam pada jaringan.

Menurut Handayanto et al., (2017) fitoremediasi memiliki beberapa teknik untuk menghilangkan polutan dari tanah yaitu fitoekstraksi, fitofiltrasi, (rhizofiltrasi), fitodegradasi (fitotransformasi) fitostabilisasi dan fitovolatilizasi. Fitoekstraksi yaitu penyerapan suatu senyawa pencemar dari tanah atau air oleh akar tanaman dan ditranslokasi serta diakumulasikan di dalam bagian atas tanah, yaitu tajuk tanaman seperti akar, batang dan daun. Rhizofiltrasi yaitu penggunaan akar tumbuhan, digunakan untuk menyerap bahan pencemar terutama logam dari air, tanah dan air limbah. Fitodegradasi adalah degradasi pencemar organik oleh tumbuhan dengan bantuan enzim dehalogenase dan oksigenase dimana tumbuhan dapat mengakumulasi xenobiotic organik dari lingkungan tercemar sera mendetoksifikasi melalui metabolisme tanaman. Fitostabilisasi yaitu proses yang dilakukan tanaman untuk mentransformasikan polutan di dalam tanah menjadi senyawa yang non toksik tanpa menyerap terlebih dahulu polutan tersebut ke dalam tubuh tanaman. Fitovolatilisasi yaitu tanaman digunakan untuk penyerapan unsur beracun dari dalam tanah lalu menguapkannya dari daun.

Tanaman kayu apu dalam proses pengontakan mengalami perubahan morfologi karena merupakan sebuah bentuk respon tanaman kayu apu diakibatkan kontak langsung dengan air limbah yang mengandung logam berat. Pada penelitian ini terjadi perubahan fisik tanaman yaitu perubahan warna pada daun menjadi kuning dan akar mulai rontok. Hal ini juga terjadi pada penelitian (Khasanah et al., 2018) dimana kayu apu dikontakan dengan limbah cair yang mengandung logam berat merkuri $(\mathrm{Hg})$ mengalami perubahan yang sama yaitu ditandai dengan kondisi daun yang mulai berwarna kekuningan dan akhirnya mati serta akar tanaman juga mengalami kerontokan. Berdasarkan penelitian (Fachrurozi et al., 2010) perubahan warna pada daun disebabkan oleh menurunnya klorofil akibat dari beban polutan yang tinggi. Menurut Purnama et al., (2018) tanaman kayu apu yang ditanam pada konsentrasi tinggi akan berdampak pada penurunan metabolisme sehingga mengakibatkan jaringan sel dalam akar cepat rusak, hal ini akan berdampak pada produksi fitokelatin. Fitokelatin berfungsi sebagai detoksifikasi terhadap tanaman dari logam berat misalnya dengan penimbunan logam di dalam organ tertentu seperti akar dan lateks. Tanaman kayu apu mengandung fitokelatin yang banyak. Fitokelatin pada tanaman kayu apu terdapat pada akar dan daun tanaman (Utami et al., 2017). Penurunan metabolisme ditandai dengan perubahan fisik pada daun yang semakin lama akan berubah warna menjadi kekuningan serta daun akan mengalami kerontokan. Penurunan 
metabolisme diakibatkan oleh hiperakumulasi ion logam yang berlebih.

\section{SIMPULAN}

Rerata kadar Cr total pada kelompok tanpa kayu apu atau kelompok kontrol adalah sebesar $0.509 \mathrm{mg} / \mathrm{L}$. Rerata kadar kelompok perlakuan dengan penambahan kayu apu yaitu P1 dengan berat tanaman $300 \mathrm{gr} / 6 \mathrm{~L}$ sebesar $0.371 \mathrm{mg} / \mathrm{L}$, kelompok perlakuan kedua yaitu $\mathrm{P} 2$ dengan berat tanaman $350 \mathrm{gr} / 6 \mathrm{~L}$ sebesar $0.293 \mathrm{mg} / \mathrm{L}$ dan kelompok perlakuan ketiga yaitu P3 dengan berat tanaman $400 \mathrm{gr} / 6 \mathrm{~L}$ sebesar $0.165 \mathrm{mg} / \mathrm{L}$. Berdasarkan Peraturan Gubernur Jatim No. 52 tahun 2014 kadar Cr-T pada semua kelompok sudah di bawah Baku Mutu Lingkungan yaitu 1 $\mathrm{mg} / \mathrm{L}$. Kelompok K dengan kelompok perlakuan memiliki perbedaan kadar Cr-T yaitu dilihat dari nilai signifikansinya. Nilai signifikansi empat kelompok adalah P1 sebesar 0.007, P2 sebesar 0.0042 dan P3 sebesar 0.000. Nilai signifikansi menunjukkan perlakuan yang paling efektif yaitu terdapat pada kelompok P3 dengan penambahan berat paling banyak yaitu $400 \mathrm{gr} / 6 \mathrm{~L}$ tanaman kayu apu dengan waktu kontak 10 hari.

\section{UCAPAN TERIMA KASIH}

Terima kasih kepada Andrei Ramani, S.KM., M.Kes, Ellyke, S.KM., M.KL dan Eka Agustina, S.T. selaku dosen penguji. Terima kasih juga terhadap Industri Batik X yang telah memberikan sampel limbah cair batik dalam penelitian ini serta Laboratorium Kesehatan Daerah Kabupaten Jember sebagai tempat pengecekan kadar logam chromium total pada limbah cair batik.

\section{KEPUSTAKAAN}

Andriani R, Hartini. 2017. Toksisitas Limbah Cair Industri Batik Terhadap Morfologi Sisik Ikan Nila Gift (Oreochomis Nilotocus). Jurnal SainHealth 1(2): 32-40.

Fachrurozi M, Utami LB, Suryani D. 2010. Pengaruh Variasi Biomassa Pistia Stratiotes L. Terhadap Penurunan Kadar Bod, Cod, Dan Tss Limbah Cair Tahu Di Dusun Klero
Sleman Yogyakarta. Jurnal Kesehatan
Masyarakat (Journal of Public Health) 4(1):
$\begin{aligned} & 1-16 . \\ & \text { 10.12928/kesmas.v4i1.1100. }\end{aligned}$

Handayanto E, Nuraini Y, Muddarisna N, Syam N, Fiqri A. 2017. Fitoremediasi dan Phytomining Logam Berat Pencemar Tanah. Malang: UB Press.

Hapsari S, Zaman B, Andarani P. 2016. Kemampuan Tumbuhan Kayu Apu (Pistia stratiotes L.) dalam Menyisihkan Kromium Total (Cr-T) dan COD Limbah Elektroplating. Jurnal Teknik Lingkungan. 5(4): 1-9.

Henrasarie N. 2019. Kemampuan Adsorbsi Pb dari Limbah Industri oleh Tumbuhan Kayu Ambang (Lemna minor), Kayu Apu (Pistia stratiotes) dan Eceng Gondok (Eichhornia crassipes solm). Jurnal Envirotek 11(1): 3945. https://doi: 10.33005/envirotek.v11i1.1368.

Herlambang P, Hendriyanto O. 2015. Fitoremediasi Limbah Detergen Menggunakan Kayu Apu (Pistia stratiotes L.) dan Genjer (Limnocharis flava L.) Jurnal Ilmiah Teknik Lingkungan 7(2): 115-124.

Ikawati S, Zulfikar A, Azizah D. 2013. Efektivitas Dan Efisiensi Fitoremediasi Pada Deterjen Dengan Menggunakan Tanaman Genjer (Limnocharis Flava). http://jurnal.umrah.ac. id/wp-content/uploads/2013/08/SariIkawati090254242080.pdf.

Irhamni, Pandia S, Purba E, Hasan W. 2018. Kajian Akumulator Beberapa Tumbuhan Air dalam Menyerap Logam Berat secara Fitoremediasi. Jurnal Serambi Engeneering 3(2): 344-351. https://doi: 10.5281/ZENODO.400012.

Jamil A, Darundiati YH, Dewanti NAY. 2016. Pengaruh Variasi Lama Waktu Kontak Dan Jumlah Tanaman Kayu Apu (Pistia Stratiotes) Terhadap Penurunan Kadar Cadmium (Cd) Limbah Cair Batik Home Industry " $\mathrm{X}$ " Di Magelang. Jurnal Kesehatan Masyarakat Universitas Diponegoro 4(4): 763-770. 
Khasanah M, Moelyaningrum AD, Pujiati RS. 2018. Analisis perbedaan tanaman kayu apu (Pistia stratiotes) sebagai fitoremediasi merkuri (Hg) pada air. Sanitasi: Jurnal kesehatan lingkungan 9(3): 105-110.

Nurkhasanah S. 2015. Kandungan Logam Berat Kromium (Cr) Dalam Air, Sedimen, dan Ikan Nila (Oreochromis Niloticus) serta Karakteristik Biometrik dan Kondisi Histologisnya di Sungai Cimanuk Lama, Kabupaten Indramayu. [Tesis] Sekolah Pascasarjana Institut Pertanian Bogor, Institut Pertanian Bogor.

Perwitasari P, Handayanto E, Rindyastuti R. 2018. Penggunaan Echinodorus Radicans dan Pistia Stratiotes Untuk Fitoremediasi Air Tercemar Timbal $(\mathrm{Pb})$ Serta Pengaruhnya Terhadap Tanaman Amaranthus Tricolor. Jurnal Tanah dan Sumberdaya Lahan 5(1): 2549-9793.

Pridyanti DD, Moelyaningrum AD, Ningrum PT. 2018. Pemanfaatan Limbah Cangkang Kupang (Corbula Faba) Teraktivasi Termal Sebagai Adsorben Logam Kromium (Cr6+) Pada Limbah Cair Batik. Jurnal Hibualamo: Seri Ilmu-ilmu Alam dan Kesehatan 2(2): 63-68.

Purnama MS, Kusumawati E, Susanto D. 2018. Fitoremediasi Menggunakan Kayu Apu (Pistia stratiotes L.) dalam Kolam Bekas Tambang Batubara Terhadap Penyerapan Logam Mangan (Mn) dan Kadmium (Cd). Jurnal Bioprospek 13(1): 33-39.

Purnamawati KY, Budiarsa Suyasa I, Mahardika I. 2015. Penurunan Kadar Rhodamin B Dalam Air Limbah Dengan Biofiltrasi Sistem Tanaman. Jurnal ECOTROPHIC 9(2): 4651. 10.24843/ejes.2015.v09.i02.p08.

Rahayuningtyas I, Wahyuningsih NE, Budiyono. 2018. Pengaruh Variasi Lama Waktu Kontak Dan Berat Tanaman Apu-Apu (Pistia Stratiotes L.) Terhadap Kadar Timbal Pada Irigasi Pertanian. Jurnal Kesehatan Masyarakat 6(6): 166-174.

Raissa DG. 2017. Fitoremediasi Air yang Tercemar Limbah Laundry dengan Menggunakan Eceng Gondok (Eichhornia crassipes) dan Kayu Apu (Pistia stratiotes). [Skripsi] Surabaya: Jurusan Teknik Lingkungan. Institut Teknologi Sepuluh November.

Raissa DG, Tangahu BV. 2017. Fitoremediasi Air yang Tercemar Limbah Laundry dengan Menggunakan Kayu apu (Pistia stratiotes). Jurnal Teknik ITS 6(2): 7-11. https://doi: 10.12962/j23373539.v6i2.25092.

Sari AM, Rachmadiarti F, Fitrihidayati H. 2014. Pengaruh Cekaman Kromium pada Limbah Cair Batik terhadap Pertumbuhan Eichornia crassipes dan Salvinia molesta. Jurnal Lentera Bio 3(1): 67-71.

Sari NWM, Diara IW, Trigunasih NM. 2017. Meningkatkan Kualitas Air Irigasi dengan Menggunakan Tanaman Kayu Apu (Pistia stratiotes L.) dan Tanaman Azolla (Azolla sp.) di Subak Sembung, Peguyangan, Denpasar. Journal of Tropical Agroecotechnology 6(1): 82-90.

Setiyono A, Gustaman RA. 2017. Pengendalian Kromium (Cr) Yang Terdapat Di Limbah Batik Dengan Metode Fitoremediasi. Unnes Journal of Public Health 6(3): 155-160. https://doi: 10.15294/ujph.v6i3.15754.

Utami LD, Narwati, Rahayu U. 2017. Kemampuan Tanaman Apu-apu (Pistia stratiotes L.) dalam Menurunkan Kadar Logam Berat Nikel (Ni) Limbah Cair. Jurnal Gema Kesehatan Lingkungan 15(1): 46-51.

Wirawan WA, Wirosoedarmo R, Susanawati LD. 2014. Pengolahan Limbah Cair Domestik Menggunakan Tanaman Kayu Apu (Pistia stratiotes L.) dengan Teknik Tanam Hidroponik Sistem DFT (DeepFlowTechnique). Jurnal Sumberdaya Alam dan Lingkungan 1(2): 63-70.

Zarkasi K, Moelyaningrum AD, Trirahayu NP. 2018. Penggunaan Arang Aktif Kulit Durian (Durio Zibethinus Murr) Terhadap Tingkat Adsorpsi Kromium (Cr6+) Pada Limbah Batik. Jurnal Efektor 5(2): 67-73. 